File 2799, 43(4) 2nd Print (1)

\author{
Avaiable online at www.banglajol.info \\ Bangladesh J. Sci. Ind. Res. 43(4), 455-466, 2008
}

BCSIR

\author{
BANGLADESH JOURNAL \\ OF SCIENTIFIC AND \\ INDUSTRIAL RESEARCH \\ E-mail: bjsir07gmail.com
}

\title{
Chromium(VI) Reducing Native Microorganisms for Remediation of Chromium Eco-toxicity in Environment of Bangladesh
}

\author{
Iftekhar M. Rafiqullah, ${ }^{a}$ A. M. M. Maruf Hossain, ${ }^{* b}$ Mohammad Ilias $^{a}$ \\ and M. Mozammel Hoq ${ }^{\mathrm{a}}$ \\ ${ }^{a}$ Department of Microbiology, University of Dhaka and ${ }^{b}$ Department of Soil, Water and Environment, \\ Faculty of Biological Sciences, University of Dhaka, Dhaka, Bangladesh
}

\begin{abstract}
Feeds and fertilizer production from tanned skin-cut wastes is the most direct phenomenon of chromium eco-toxicity leading to food chain contamination in Bangladesh. Tanning industries of Hazaribagh at Dhaka process some $220 \mathrm{t}$ of hide per day with release of $600-1000 \mathrm{Kg}$ tanned skin-cut waste (SCW) per ton processed hide. The SCW is protein-rich and unscientifically used to produce poultry and fish feeds, and organic fertilizer. A huge migration of chromium can happen into poultry products, fish and vegetables, and further bio-magnify into food chain. The target population is also huge. It is reported that feed ingredients produced from SCW contained chromium at levels as high as $2.49 \%$. As $\mathrm{Cr}(\mathrm{VI})$ is the most toxic species of chromium, reduction of $\mathrm{Cr}(\mathrm{VI})$ to $\mathrm{Cr}(\mathrm{III})$ prior to be used as feed ingredients and fertilizers can ensure safer input of chromium in toxicological point of view. Samples have been collected to isolate microorganisms from effluent sites of Hazaribagh tanning area using Lauria-Bertani medium with added $\mathrm{Cr}(\mathrm{VI})$ as $\mathrm{K}_{2} \mathrm{Cr}_{2} \mathrm{O}_{7}$. The successful as well as apparently differing colonies (isolates IF-10 to IF-12, IF-16, and IF-19 to IF-23) have been studied for growth characterization under differing $\mathrm{Cr}(\mathrm{VI})$ concentrations up to $1500 \mathrm{mg} / \mathrm{L}$. Cultural and biochemical tests of the isolates have narrowed the range into 3 strains. These strains have been identified by 16s rRNA gene sequence analysis. The isolates are found to be Escherichia sp. (Isolate IF-10 to IF-12, Strain IFR-I), Staphylococcus aureus (Isolate IF-16, Strain IFR-II), and Pediococcus pentosaceus (Isolate IF-19 to IF-23, Strain IFRIII). The organisms have been studied for Cr (VI) reduction-ability in growth dependent manner which are found successful up to $82.88 \%$ for Staphylococcus aureus, and $100 \%$ for Escherichia sp. and Pediococcus pentosaceus within $24 \mathrm{~h}$.
\end{abstract}

Key words: Bacteriology, Enzymatic reduction, Bioremediation, Chromium eco-toxicity

\section{Introduction}

Leather, a traditional export item in wide for its quality. This sector plays a signifBangladesh, enjoys a good reputation world icant role in the economy of Bangladesh in 
terms of its contribution to export and domestic market. In south-western part of Dhaka city, there is a tannery area occupying 25 hectares of land at Hazaribagh, where about $90 \%$ of tannery industries of Bangladesh are located. The tanning industries of Hazaribagh process some $220 \mathrm{t}$ of hide per day with an associated release of $600-1000 \mathrm{Kg}$ of tanned skin-cut waste (SCW) per ton processed raw hide (Zahid, et al., 2004). The SCW are sliced cut pieces of hides produced at the end of some tanning processes to maintain a definite thickness. Being of protein origin, these wastes are converted to protein-concentrate to be used as poultry feed, fish feed, and in production of organic fertilizers with some treatment. One of the major concerns of these activities is the heavy metals, especially, chromium used in the tanning processes. Large amounts of chrome powder and chrome liqueur are used during tanning process. Used $47 \%$ collagen and $85 \%$ chemicals enter the waste streams as effluent (UNIDO, 2000).

There are many environmental hazards associated with the chemicals used in the tanning processes. But the hazards can come out in two ways. One is through the waters of canals and rivers after mixing with effluents. Substantial work has been done to study on this. But the other way, which is only recently been studied by Hossain et al. (2007), is the entrance of harmful chemicals into the food chain through the use of SCW as feed stuff. This is a recent phenomenon happening at large extent for the last several years.

Hossain et al. (2007) have reported that protein-concentrates produced from SCW are found to contain chromium at levels as high as $2.49 \%$. This suggests that a huge migration of chromium can take place into poultry products, fish and vegetables through use of the protein-concentrates, and further biomagnify into food chain. Zahid et al. (2004) have reported that chromium concentrations in effluents and canal water was $4.06 \mathrm{ppm}$ and $0.443 \mathrm{ppm}$, respectively; whereas suspended materials in effluents and canal water contained as high as $2.88 \%$ and $2.02 \%$, respectively. These waters can also have multiplier indirect effects for chromium toxicity.

For the removal of toxic chromium, the conventional methods can include chemical reduction followed by precipitation, ion exchange, and adsorption on activated coal, alum, kaolinite, and ash. However, most of these methods require either high energy or large quantities of chemical reagents. These also affect aquatic lives. Alternatively, bioremediation through microbial reduction of toxic hexavalent chromium has practical importance, because biological strategies provide green technology that is also cost effective. More specifically, chromium tolerant bacteria are prominent source of chromium reductase enzyme (Fendorf et al., 2000). 


\section{Materials and Methods}

Study area and sampling

The study area is comprised of the tannery area at Hazaribagh Thana which is situated on the south-western part of Dhaka city. For collection of tannery effluent from drain water five different sites have been selected from Hazaribagh Tannery area to Rayerbazar sluice gate area, which are shown in Fig. 1. Sampling has been done twice from the sites in January, 2007 and March, 2007.

\section{Isolation}

A volume of $100 \mu \mathrm{L}$ from each effluent/drain water sample is inoculated on LB agar plate with addition of $500 \mathrm{mg} / \mathrm{L} \mathrm{Cr}(\mathrm{VI})$ (as $\mathrm{K}_{2} \mathrm{Cr}_{2} \mathrm{O}_{7}$ ) and incubated at $37^{\circ} \mathrm{C}$ for 4 days. From the twice sampling and all agar plates, a total of 24 colonies have been selected and identified as IF-1 to IF-24. These colonies are isolated by sub-culturing onto fresh LB broth medium with same concentration of added $\mathrm{Cr}(\mathrm{VI})$ and only 9 isolates survived. The isolates were IF-10 to IF-12, IF-16 and

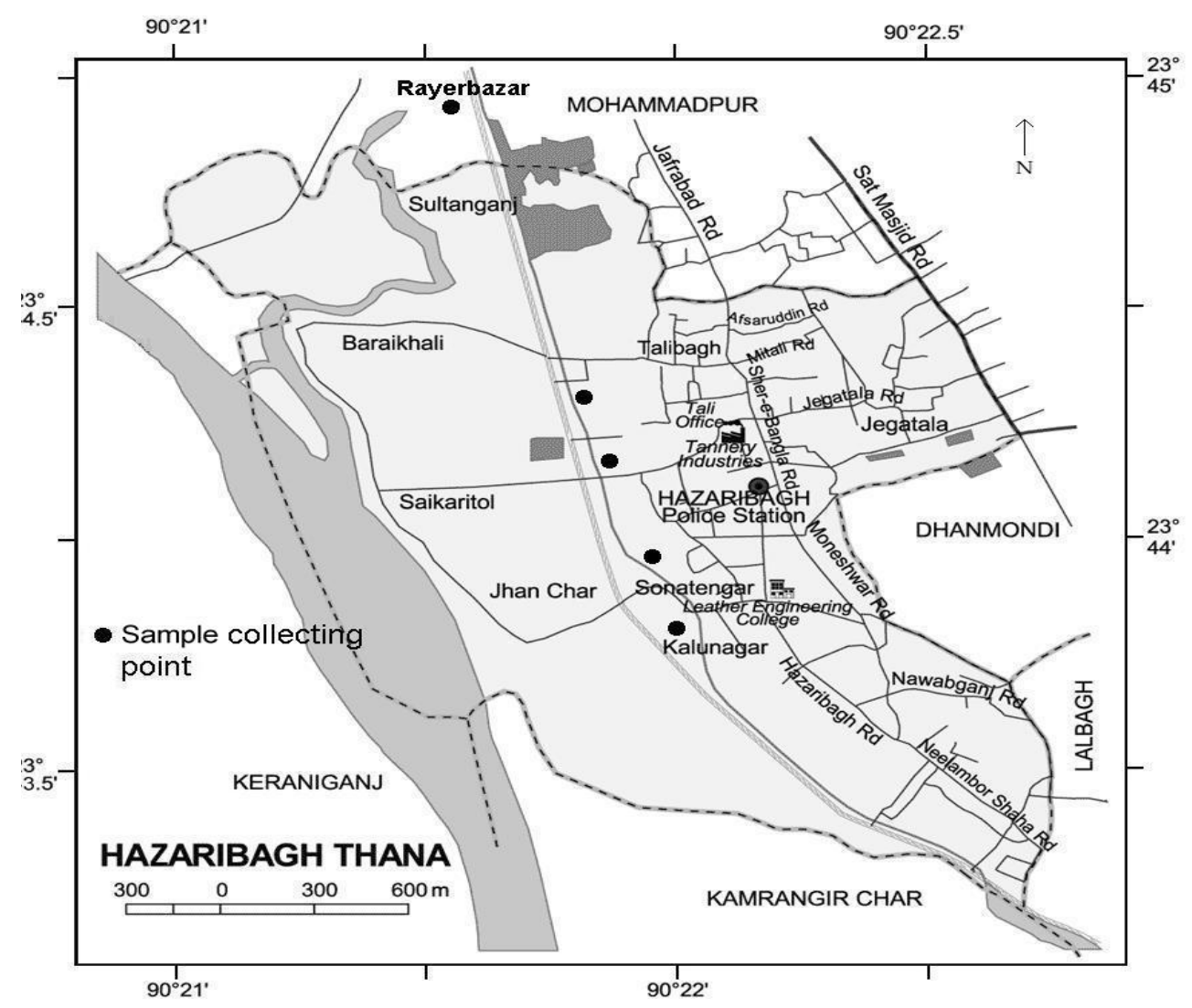

Fig. 1. Map of Hazaribagh showing sample collection points 
IF-19 to IF-23. These 9 isolates are studied further.

\section{Characterization of growth under varying $\mathrm{Cr}(\mathrm{VI})$ concentration}

The 9 isolates are inoculated into LB broth medium with varying concentrations of added $\mathrm{Cr}(\mathrm{VI})$. The tolerance of the isolates on $\mathrm{Cr}(\mathrm{VI})$ concentrations of 0 (positive control), 500, 1000, and $1500 \mathrm{mg} / \mathrm{L}$ are examined in LB broth medium incubated in shake flask culture at $150 \mathrm{rpm}$ and $37^{\circ} \mathrm{C}$ for various time intervals. Growth of the isolates in varying $\mathrm{Cr}(\mathrm{VI})$ concentration is equivalent to the bacterial cell density of the liquid cultures which is reflected in optical density (OD) of the supernatants measured at 600 nm.

\section{Cultural and biochemical tests}

Cultural and biochemical tests have been conducted in order to avoid the involvement of similar type of microorganism in $\mathrm{Cr}(\mathrm{VI})$ reduction studies. The shape and type of Gram reaction are microscopically studied using 18 hour culture from agar plate. Other cultural tests are performed which include selective and differential media such as MacConkey (MAC) Agar, Sorbitol MacConkey (SMAC) Agar, Xylose Lysine Deoxycholate (XLD) Agar, Mannitol Salt (MSA) Agar, and Eosine Methylene Blue (EMB) Agar. The biochemical tests involved Kliger's Iron Agar (KIA), Simmon's Citrate Slant, Motility Indole Urease (MIU), Motiliy
Indole Ornithase (MIO), Peptone water, Methyl Red (MR), Voges-Proskauer (VP), Nutrient Nitrate Broth (NB), Oxidase, and Catalase tests.

From the results of the cultural and biochemical tests, it is found that the isolates IF-10 to IF-12 are similar, IF-19 to IF-23 are alike and IF-16 is different from others. So, finally three different bacterial strains are found out of the nine isolates. These strains are named as IFR-I (IF-10 to IF-12), IFR-II (IF16), and IFR-III (IF-19 to IF-23). Pure cultures are prepared for these strains to conduct further studies.

\section{$\mathrm{Cr}(\mathrm{VI})$ reduction by the strains in growth dependent manner}

The cultured three strains are studied for $\mathrm{Cr}(\mathrm{VI})$ reduction in growth dependent manner. The strains are inoculated from pure cultures into broth medium with added $\mathrm{Cr}(\mathrm{VI})$ to obtain resultant $\mathrm{Cr}(\mathrm{VI})$ concentration of $10 \mathrm{mg} / \mathrm{L}$. Before addition of $\mathrm{Cr}(\mathrm{VI})$ into inoculums, they are incubated for one hour in shake flask culture at $150 \mathrm{rpm}$ and $37^{\circ} \mathrm{C}$. Then the optical density of the inoculums is adjusted around 0.60 at $600 \mathrm{~nm}$ as a measure for equal enzyme activity. After adding $\mathrm{Cr}(\mathrm{VI})$, the cultures are again incubated for 24 hour in shake flask culture at $150 \mathrm{rpm}$ and $37^{\circ} \mathrm{C}$. After that the broth cultures are centrifuged using falcon tube at $5000 \mathrm{rpm}$ for 15 minutes. The supernatants are separated and pellets of organisms are kept under freezing condition. The remaining $\mathrm{Cr}(\mathrm{VI})$ concentra- 
tions in the supernatants are measured in comparison to the initial $10 \mathrm{mg} / \mathrm{L}$.

\section{Chromium (VI) assay}

Hexavalent chromium has been determined colorimetrically by the s-diphenylcarbazide (DPC) method using a spectrophotometer (Spectronic-Genesys-5, USA) (Bartlett and James, 1996).

\section{Identification by 16S rRNA gene sequence}

Genomic DNA of bacterial isolates has been isolated according to the method described by Sambrook et al. (1989). Gene fragments specific for the highly variable V3 region of the bacterial 16S rDNA has been amplified by PCR as described by Ovreas et al. (1997) using universal bacterial primers L340GCF and K517R (Sigma, USA) in a thermal cycler (MJ Research Inc., Watertown, USA). The sequence of the L340GCF primer, which included a 40 base pair GC-clamp attached to the 5'-end, is 5'- CGCCCGCCGG CGCGGCGG G C G G G GCGGGGGCA CGGGGGGAC T C C TACGGGAGGCAGCAG - 3' and the sequence of the K517R primer is 5'-ATTACCGCGGCTGCTGG-3'. The PCR products are subjected to $2 \%$ agarose gel electrophoresis, stained with ethidium bromide and visualized on a UV transilluminator for the presence of about 200 bp PCR products.
Amplified 16S rDNA products are purified using StrataPrep ${ }^{\circledR}$ PCR purification kit according to the manufacturers' protocol. Sequencing reactions are carried out using ABI-Prism Big dye terminator cycle sequencing ready reaction kit and the PCR products are purified by a standard protocol. The purified cycle sequenced products are analyzed with an ABI-Prism 310 genetic analyzer. The chromatogram sequencing files are edited using Chromas 2.32 (Technelysium, Queensland, Australia). The homology of the 16S rDNA sequences is checked with the 16S rDNA sequences of other organisms that had already been submitted to Gen Bank database using the BLASTN (Altschul et al., 1990; http:// www.ncbi.nih.gov/ BLAST/) algorithm.

\section{Results and Discussion}

\section{Characterization of growth under varying Cr(VI) concentration}

Characterization of growth of nine $\mathrm{Cr}(\mathrm{VI})$ tolerant (at $500 \mathrm{mg} / \mathrm{L}$ ) isolates (isolate IF-10 to IF-12, IF-16, and IF-19 to IF-23) under varying $\mathrm{Cr}(\mathrm{VI})$ concentration [0 (positive control)], 500, 1000, and $1500 \mathrm{mg} / \mathrm{L}]$ are represented in Figs. 2, 3 and 4 (fig. numbers varied to reflect groupings of the isolates according to cultural and biochemical properties). 


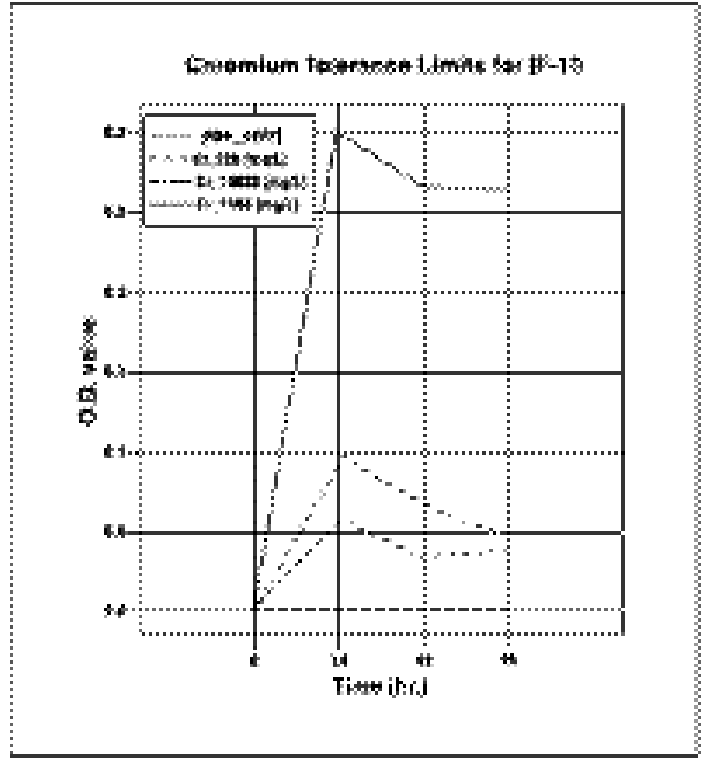

Fig. 2-A. Chromium tolerance limits for IF-10

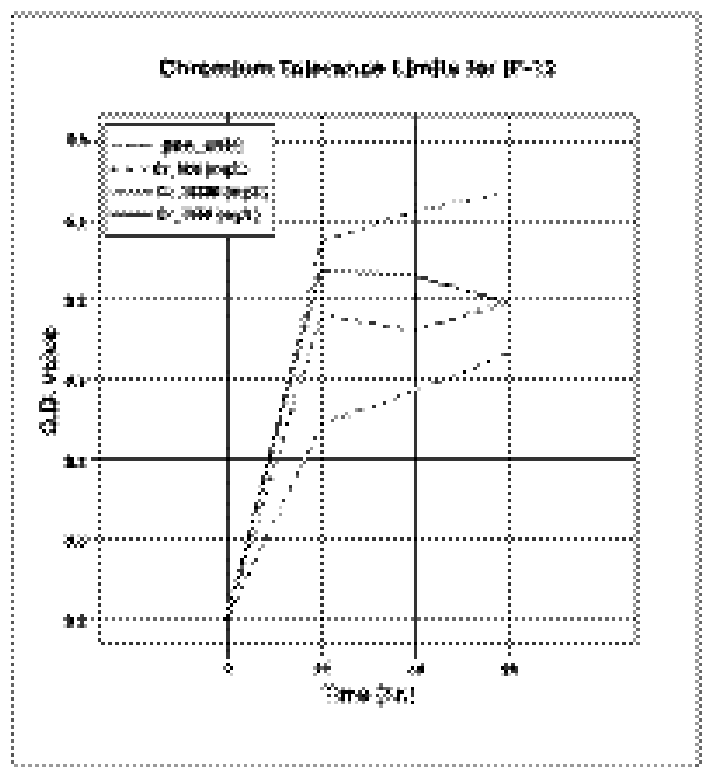

Fig. 2-C. Chromium tolerance limits for IF-12

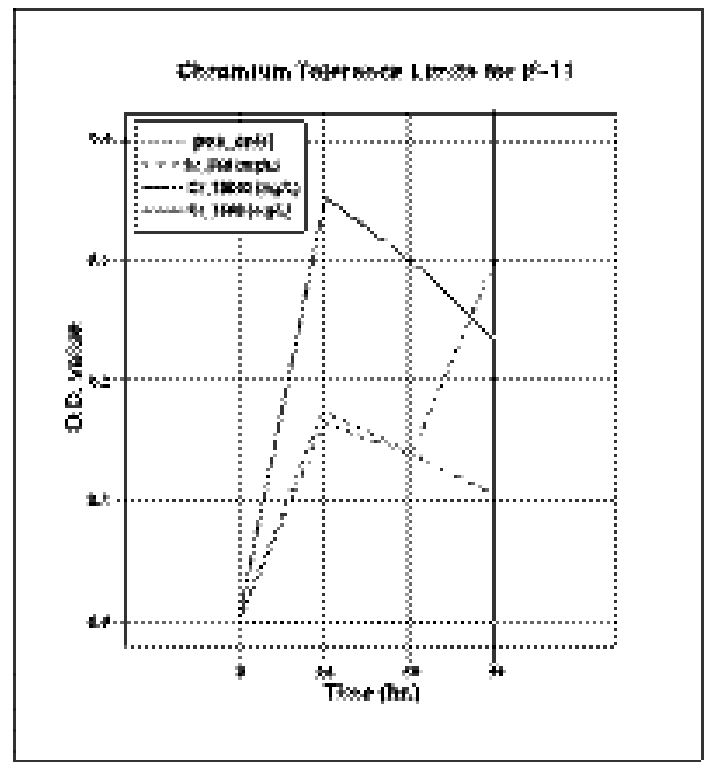

Fig. 2-B. Chromium tolerance limits for IF-11

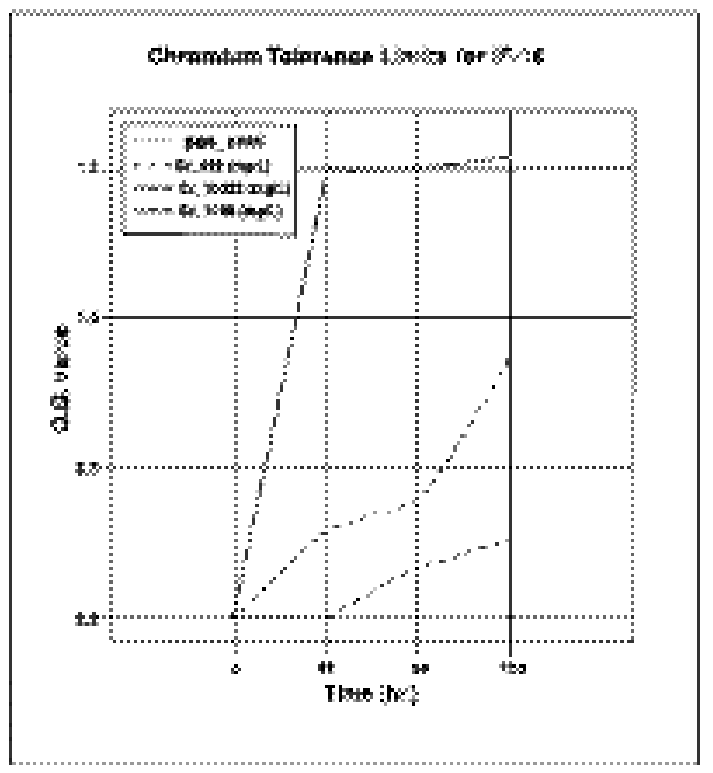

Fig. 3. Chromium tolerance limits for IF-16 


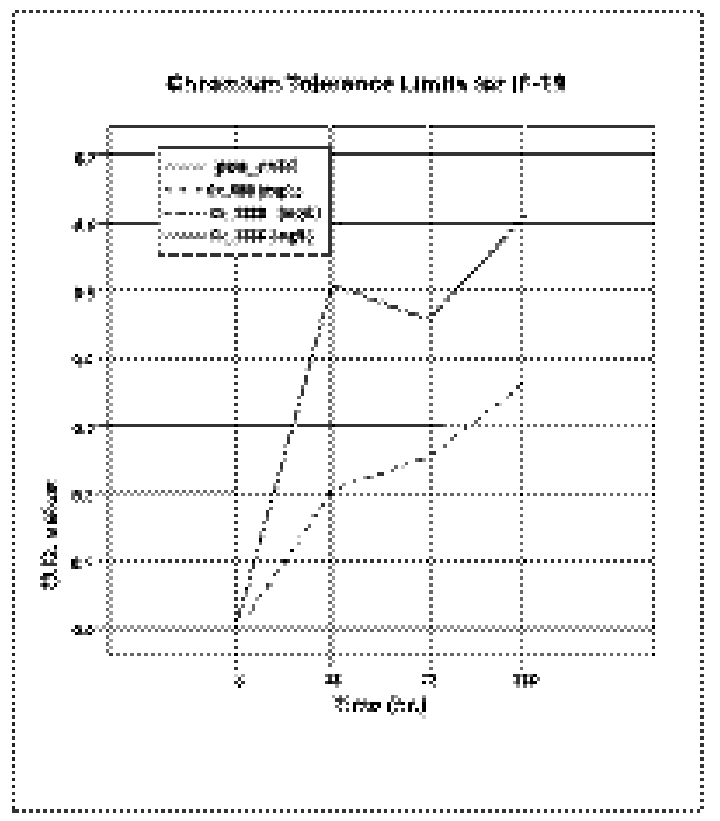

Fig. 4-A. Chromium tolerance limits for IF-19

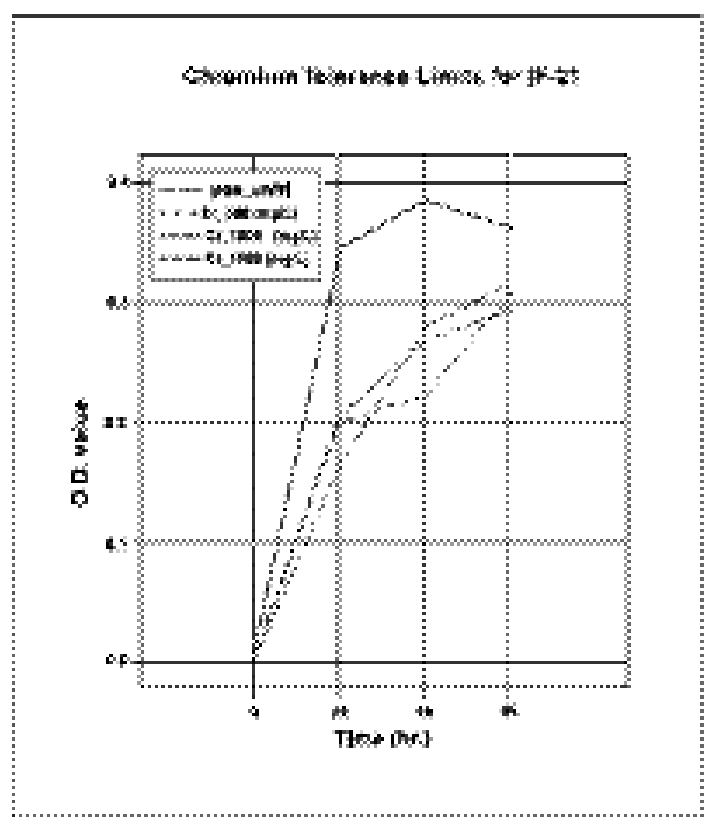

Fig. 4-C. Chromium tolerance limits for IF-21

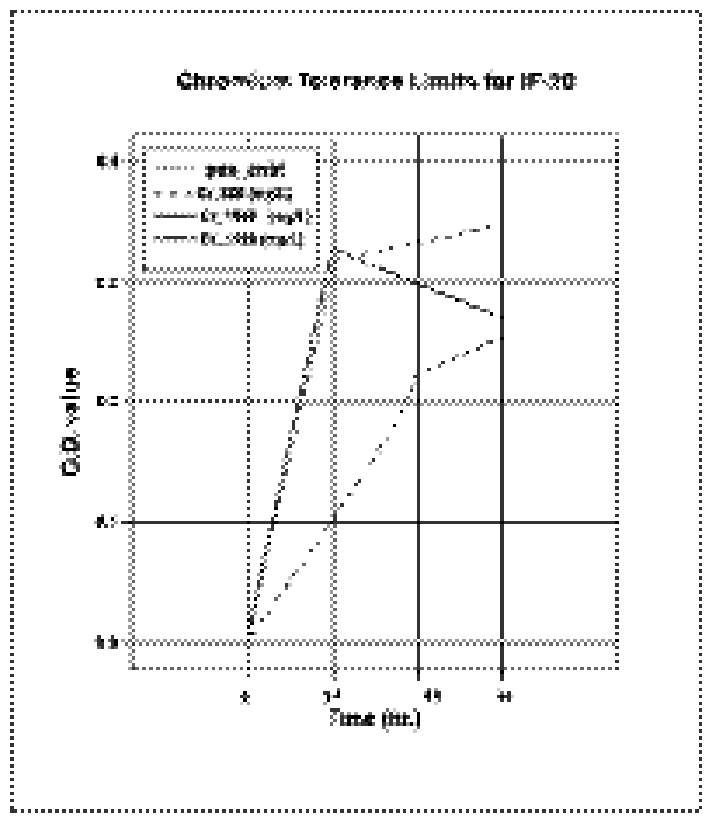

Fig. 4-B. Chromium tolerance limits for IF-20

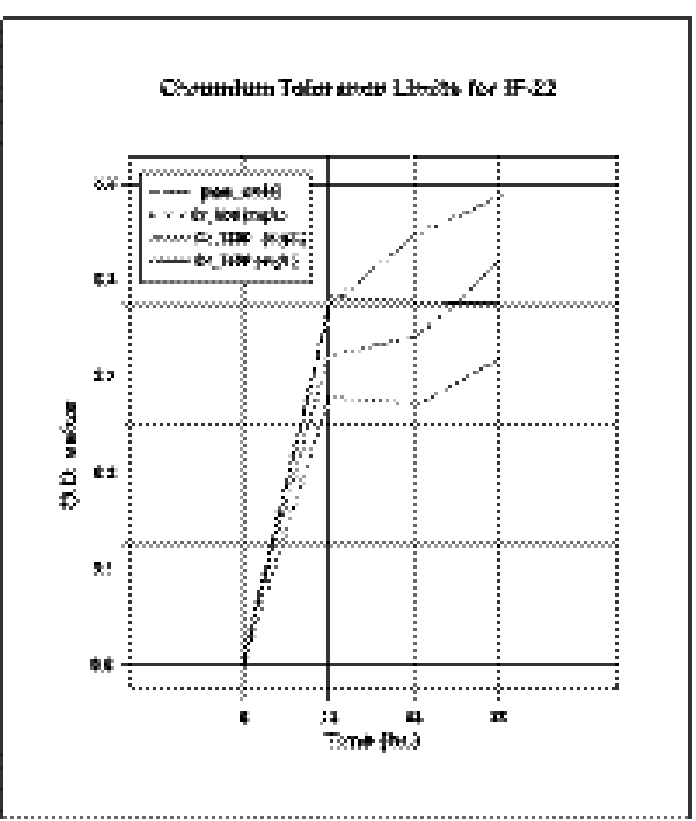

Fig. 4-D. Chromium tolerance limits for IF-22 


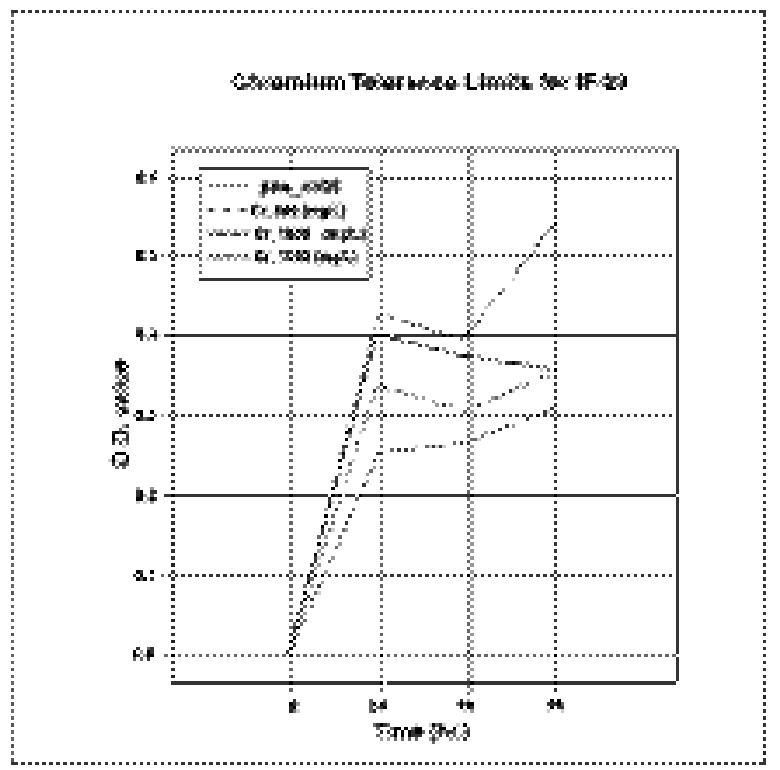

Fig. 4-E. Chromium tolerance limits for IF-23

\section{Cultural and biochemical tests}

The cultural and biochemical properties exhibited by the isolates produce only three different sets of results, based on which three different strains are obtained. These strains are named as IFR-I (IF-10 to IF-12), IFR-II (IF-16), and IFR-III (IF-19 to IF-23). The results of cultural and biochemical tests are grouped by the three differing strains (IFR-I to IFR-III) in Table I.

$\mathrm{Cr}(\mathrm{VI})$ reduction by the strains in growth dependent manner

The added Cr(VI) reduction by the strains in growth dependent manner within $24 \mathrm{~h}$ is shown in Fig. 5.

\section{Identification of the strains}

The strains are identified by 16s rRNA gene sequence analysis and the results are given in Table II.

From Figs. 2, 3, and 4 it is clearly evident that five isolates out of nine have tolerated $\mathrm{Cr}(\mathrm{VI})$ concentration up to $1500 \mathrm{mg} / \mathrm{L}$. Though the growth expression by the isolates are differential, but a general trend of growth decrease is observed with increase in $\mathrm{Cr}(\mathrm{VI})$ concentration.

With the help of the listed cultural and biochemical tests in Table I, three different strains are identified as IFR-I (IF-10 to IF12), IFR-II (IF-16), and IFR-III (IF-19 to IF23). The $\mathrm{Cr}(\mathrm{VI})$ reduction study and identifi- 
Table I: Cultural and biochemical properties exhibited by the three strains

\begin{tabular}{|c|c|c|c|}
\hline $\begin{array}{c}\text { Properties } \\
\end{array}$ & $\begin{array}{r}\text { IFR-I } \\
\end{array}$ & IFR-II & IFR-III \\
\hline \multicolumn{4}{|c|}{ Cultural Properties: (A) Gram Staining } \\
\hline Gram Reaction & Negative & Positive & Positive \\
\hline Shape & Oval to cocci & Cocci & Cocci \\
\hline \multicolumn{4}{|c|}{\begin{tabular}{|l|l|} 
Cultural Properties: (B) Selective and Differential Media & \\
\end{tabular}} \\
\hline MacConkey (MAC) Agar & $\begin{array}{l}\text { Media color changes into } \\
\text { dark brown, colorless } \\
\text { colony, lactose negative. }\end{array}$ & Not done & Not done \\
\hline $\begin{array}{l}\text { Sorbitol MacConkey (SMAC) } \\
\text { Agar }\end{array}$ & $\begin{array}{l}\text { No growth, } \\
\text { Sorbitol negative }\end{array}$ & Not done & Not done \\
\hline $\begin{array}{l}\text { Xylose Lysine Deoxycholate } \\
\text { (XLD) Agar }\end{array}$ & $\begin{array}{l}\text { Media color turns into } \\
\text { light pink, transparent. }\end{array}$ & Not done & Not done \\
\hline $\begin{array}{l}\text { Mannitol Salt (MSA) } \\
\text { Agar }\end{array}$ & $\begin{array}{l}\text { Media turns into yellow, } \\
\text { yellow colored colony, } \\
\text { Mannitol positive. }\end{array}$ & $\begin{array}{l}\text { Media color unchanged, } \\
\text { transparent colony, } \\
\text { Mannitol negative. }\end{array}$ & No growth \\
\hline $\begin{array}{l}\text { Eosine Methylene Blue } \\
\text { (EMB) Agar }\end{array}$ & $\begin{array}{l}\text { Small sized colony, Off- } \\
\text { white colored, Lactose } \\
\text { negative }\end{array}$ & Not done & Not done \\
\hline \multicolumn{4}{|l|}{ Biochemical properties: } \\
\hline Kliger’s Iron Agar (KIA) & $\begin{array}{l}\text { Glucose positive, Lactose } \\
\text { negative, } \mathrm{H}_{2} \mathrm{~S} \text { production } \\
\text { negative. }\end{array}$ & $\begin{array}{l}\text { Glucose positive, Lactose } \\
\text { positive, } \mathrm{H}_{2} \mathrm{~S} \text { production } \\
\text { negative. }\end{array}$ & Not done \\
\hline Simmon's Citrate Slant & Citrate negative. & Citrate negative. & Citrate negative. \\
\hline $\begin{array}{l}\text { Motility Indole Urease } \\
(\mathrm{MIU})\end{array}$ & $\begin{array}{l}\text { Urease negative, Non- } \\
\text { motile. }\end{array}$ & $\begin{array}{l}\text { Urease negative, } \\
\text { Non-motile. }\end{array}$ & $\begin{array}{l}\text { Urease negative, } \\
\text { Non-motile. }\end{array}$ \\
\hline $\begin{array}{l}\text { Motiliy Indole Ornithase } \\
\text { (MIO) }\end{array}$ & $\begin{array}{l}\text { Ornithine positive, Non- } \\
\text { motile. }\end{array}$ & $\begin{array}{l}\text { Ornithine negative, Non- } \\
\text { motile. }\end{array}$ & $\begin{array}{l}\text { Ornithine posi- } \\
\text { tive, Non- } \\
\text { motile. }\end{array}$ \\
\hline Peptone water & Indole positive. & Indole negative. & Indole positive. \\
\hline Methyl Red (MR) & MR positive. & MR negative. & MR positive. \\
\hline Voges-Proskauer (VP) & VP negative. & VP negative. & VP negative. \\
\hline $\begin{array}{l}\text { Nutrient Nitrate } \\
\text { Broth (NB) }\end{array}$ & $\begin{array}{l}\text { Nitrate production } \\
\text { negative. }\end{array}$ & $\begin{array}{l}\text { Nitrate production } \\
\text { positive. }\end{array}$ & $\begin{array}{l}\text { Nitrate } \\
\text { production } \\
\text { negative. }\end{array}$ \\
\hline Oxidase & Oxidase negative. & Oxidase negative. & $\begin{array}{l}\text { Oxidase } \\
\text { negative. }\end{array}$ \\
\hline Catalase & Catalase positive. & Catalase positive. & $\begin{array}{l}\text { Catalase } \\
\text { negative. }\end{array}$ \\
\hline
\end{tabular}




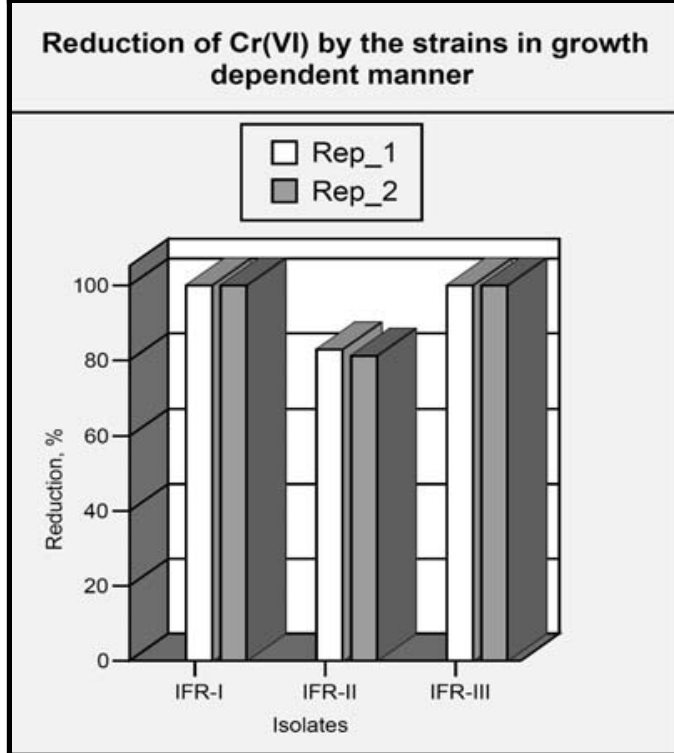

Fig. 5. Cr(VI) reduction in growth dependent manner

cation by 16s rRNA gene sequencing are conducted on these strains. Table II lists the organisms identified by gene sequencing. Results of cultural and biochemical tests conducted on the strains conform to the characteristics of the identified organisms.

Table II: Identification of the isolates

\begin{tabular}{c|c}
\hline Isolates & Organism \\
\hline IFR-I & Escherichia sp. \\
IFR-II & Staphylococcus aureus \\
IFR-III & Pediococcus pentosaceus \\
\hline
\end{tabular}

Study on Cr(VI) reduction ability in growth dependent manner is successful up to 82.878\% for Staphylococcus aureus (IFRII), and $100 \%$ for Escherichia sp. (IFR-I) and Pediococcus pentosaceus (IFR-III) within 24h.

\section{Toxicity of chromium}

Both acute and chronic toxicity of chromium are mainly caused by hexavalent compounds. The higher toxicity and mobility of $\mathrm{Cr}(\mathrm{VI})$ compared to $\mathrm{Cr}$ (III) causes it to be of greater concern (Ross et al., 1981). The most commonly used chromium compound in the tanneries of Hazaribagh is basic chromium sulfate (BCS). Though this compound is initially trivalent but gets oxidized under different harsh conditions of higher temperature, $\mathrm{pH}$ and aeration to hexavalent chromium, which is toxic and carcinogenic.

The most important toxic effects, after contact, inhalation, or ingestion of hexavalent chromium compounds include dermatitis, allergic and eczematous skin reactions, skin and mucous ulcerations, perforation of the nasal septum, allergic asthmatic reactions, bronchial carcinomas, gastro-enteritis, hepatocellular deficiency, and renal oligo anuric deficiency (Baruthio, 1992).

In the carcinogenic behavior of chromium, chromate $\left(\mathrm{CrO}_{4}{ }^{2-}\right)$ (which is a strong oxidizing agent) is reduced intracellularly to $\mathrm{Cr}^{5+}$ inside biological system and reacts with nucleic acids and other cell components to produce mutagenic and carcinogenic effects on biological systems (Clark, 1994; McLean and Beveridge, 2001). But Cohen and Costa (2000) have mentioned about derived trivalent form of chromium to be ultimately responsible for the carcinogenic effect, which describes that hexavalent compounds 
are likely to be active carcinogens but it is more likely that the ultimate species responsible for the carcinogenic/mutagenic effects observed in vivo is the intracellularly derived trivalent form.

\section{The target population}

The target population of tannery based chromium eco-toxicity is huge. Only in case of poultry, some $48 \%$ of our farmers use hand-mixed feeds which in most cases incorporate the various protein concentrates produces from tannery solid waste as protein supplement. In 2005, about 52\% of poultry feed have been produced by feed mills and the rests by the farmers themselves. In that year about $90 \%$ broiler feeds have been produced by the feed mills, whereas only $18 \%$ layer feeds have been produced by feed mills (Poultry Business Directory, 2007). This means, most of layer farmers have used hand-mixed feeds which represents more severe health risk from eggs. In the same way, the products are supplied and added as primary protein supplements in fish culture and as organic fertilizer in vegetable farming.

\section{Conclusion}

Reduction of toxic Cr(VI) to less toxic $\mathrm{Cr}(\mathrm{III})$ form is one of the ways for combating tannery based chromium eco-toxicity in Bangladesh. Means of bioremediation can also include biosorption of chromium from the tanned SCW produced feed stuffs by microorganisms as the feed ingredients are reported to contain very high levels of chromium. Development of process with combination of biological and chemical methods that would concomitantly reduce $\mathrm{Cr}(\mathrm{VI})$ by enzyme treatment as well as precipitate $\mathrm{Cr}$ (III) by chemical reaction could make the products chromium free in larger part. Microbial remediation through reduction of $\mathrm{Cr}(\mathrm{VI})$ is of enormous use both for effluent treatment before disposal in the tanning industries as well as for treating the SCW produced feed stuff to turn it into safer input. Because $\mathrm{Cr}(\mathrm{VI})$ is totally undesirable in health perspective. As the identified isolates (Escherichia sp., Staphylococcus aureus, and Pediococcus pentosaceus) are proven to successfully reduce $\mathrm{Cr}(\mathrm{VI})$, these can be used for the development of bioremediation process. But, for industrial adoption of remediation process, studies are required on feasible production of the reductase enzyme or direct reduction of $\mathrm{Cr}(\mathrm{VI})$ by the organisms in whole cell procedure to provide economic and rapid application.

\section{References}

Altschul, S.F. W. Gish, W. Miller, E.W. Myers, Lipman, D. J.(1990). Basic local alignment search tool. J Mol Biol., 215: 403-410.

Bartlett, R.J. James, B.R. (1996). Chromium. p. 683-701. In D.L. Sparks (ed.) Methods of Soil analysis. Part 3. SSSA Book Ser. 5. (SSSA, Madison, WI). 
Baruthio, F. (1992). Toxic effects of chromium and its compounds. Biol. Trace Elem. Res., 32: $145-153$.

Clark, D.P. (1994). Chromate reductase activity of Enterobacter aerogenus is induced by nitrite. FEMS Microbiol. Lett. 122: 233238.

Cohen M.D. Costa, M. (2000). Chromium. pp. 173-191. In Morton Lippmann (ed.) Environmental Toxicants: Human Exposures and Their Health Effects, 2/e. (John Wiley and Sons, Inc).

Fendorf, S. Wielinga, B.W. Hansel, C.M. (2000). Chromium transformation in natural environments: the role of biological and abiological processes in chromium (VI) reduction. Int. Geol. Rev., 42: 691-701.

Hossain, A. Maruf, M.M. Monir, T. Rezwan, A.M. Haque, Ul Kazi, M.A.I. Islam, M.S. and Elahi, S.F. (2007). Heavy metal concentration in tannery solid wastes used as poultry feed and the ecotoxicological consequences. Bangladesh J. Sci. Ind. Res., 42(4): 397-416.

McLean, J. Beveridge, T.J. (2001). Chromate reduction by a pseudomonad isolated from a site contaminated with chromated copper arsenate. Appl. Environ. Microbiol., 67: 1076-1084.

Ovreas, L. Forney, L. Daae, F.L. Torsvik, V. (1997). Distribution of bacterioplankton in meromictic Lake Saelenvannet, as determined by denaturing gradient gel electrophoresis of PCR - amplified gene fragments' coding for 16s rRNA. Appl. Environ. Microbiol. 63: 3367-3373.

Poultry business Directory. (2007). Poultry Business Directory 2007. (Poultry Khamar Bichitra, Dhaka, Bangladesh).

Ross, D.S. Sjogren, R.E. Bartlett, R.J. (1981). Behavior of chromium in soils: Toxicity to microorganisms. J. of Environ. Qual., 10(2): 145.

Sambrook, J. Fritsch, E.F. Maniatis, T. (1989). Molecular Cloning: A laboratory Manual, 2/e. (Cold Spring Harbor Laboratory Press, Cold Spring Harbor, NY).

UNIDO. (2000). Regional programme for pollution control in the tanning industry in south-east Asia: chrome balance in leather processing. Prepared by Ludvik, J.

Zahid, A. Balke, K.D. Hassan, M.Q. Flegr, M. (2004). Distribution of heavy metals in tannery effluent and their influence on sediments of Hazaribagh leather processing zone, Dhaka. In M. Q. Hassan (ed.) Water Resources Management and Development in Dhaka City. (Goethe-Institut, Dhaka).

Received : June, 22, 2008;

Accepted : August 04, 2008 